\title{
A Review of Rainfall Erosivity as a Natural Factor of Gully Erosion
}

\author{
Igwe, P.U.; Eze, C.P.; Ikeji, C.A.; Uzoegbu, C.A.; Emeh, A.B.
}

${ }^{1}$ Department of Environmental Management, Chukwuemeka Odumegwu Ojukwu University, P.M.B. 02, Uli, Anambra State,

Nigeria,

\begin{abstract}
In this $21^{\text {st }}$ century which is climate changedriven with more extreme rainfall events, gully erosion is increasingly becoming a global environmental problem influenced by both natural and anthropogenic factors. This paper is a literature review of rainfall erosivity as one of the natural factors of gully erosion. The central objective of the paper is to show in a global context how rainfall erosivity has influenced gully erosion. The method used is a review of academic/journal articles, textbooks, internet materials, conference papers and publicly available materials on gully erosion and rainfall erosivity as one of its factors. Previous authors whose works were reviewed on rainfall erosivity as a factor of gully erosion have a convergent view that rainfall is the primary cause of water-induced erosion and its power to do so is known as erosivity. They were of the view that a more intense rainfall of short duration can cause gully erosion more than a less intense one for a longer period of time. The authors also have a unity of opinion that areas with high rainfall regime such as the tropics are more prone to soil erosion than areas with low rainfall events. Recommendations to reduce the influence of rainfall as a factor of soil erosion include planting of trees and grasses that reduce the impact of rainfall to detach soil particles, conservation practices such as terracing, strip cropping and contour ploughing, a shift from rain-fed agriculture to dry season farming and grants to the affected people and landholders to manage gully erosion using adaptive measures based on their indigenous knowledge.
\end{abstract}

Keywords - Gully Erosion, Rainfall Erosivity, Review, Model, Soil Loss, Sustainable Development.

\section{INTRODUCTION}

Gully erosion menace is a global phenomenon that provokes geographical instability (Dada, 2002; Abraham, 2010). It remains one of the most challenging environmental problems in the globe (Zegeye, Abiy and Tebebu, 2010; Ogbonna, 2012). The United States Global Change Research Information Office (2001) stated that approximately 90 percent of cropland in the United States is currently losing soil above the sustainable rate; the erosion rates in Asia, Africa and South America are estimated to be as high as those in the United States. In Nigeria, gully erosion is the most serious problem affecting a large population of urban and rural environments in South Eastern Nigeria (Ezeigwe, 2015). Agulu-Nanka in Anambra State is an area badly affected by gully erosion; up to 250 tonns per hectare have been lost (Kalu, 2001).

Gully erosion is a striking feature on the land surface and also an agricultural problem in the world (Igbokwe, 2008). Shit and Maiti (2002) asserted that gully erosion is one of the major devastating catastrophe that speed up soil erosion. Gully erosion is a highly visible form of soil erosion that affects geomorphological landscapes which restricts land use and threaten roads, fences, buildings and human life (Umah, Justin and Braimoh, 2016). Ofomata (2000) placed gully erosion under actual erosion which is the manifestation of the physical loss of the land due to erosion. Gullies are generally defined by their channel depth for which permanent gullies can range from 0.5$30 \mathrm{~m}$ (Soil Science Society of America, 2000). Gully erosion is the removal of soil by runoff water and often persists in narrow channels and over short periods removes the soil from a narrow area to considerable depth (Poesen, Vandekerchove, Nactergaele, Wiideness and Verstraeten, 2002).Gully erosion is described as an accelerated process under which soil is bodily displaced and transported away faster than it can be formed (Igbokwe, Akinyede, Dang, Onoa, Nnodu and Anike, 2008). It is the removal of soil from narrow channels via the accumulation of surface runoff which tends to produce more sediment than other forms of soil erosion such as rilling (Shit and Maiti, 2012).

The factors that influence gully erosion could be natural or anthropogenic. Rainfall is one of the most significant factors affecting gully erosion; duration, intensity and frequency of rainfall cause gully erosion (Romkens, Helming and Prasad, 2002). Pathak, Wani and Sudi (2005) asserted that rainfall is an important factor of gully erosion; intense rains coupled with soils prone to sealing and crusting generate high runoff volume and concentrated flow.

Ehiorobo and Audu (2012) reported that gully erosion occurs due to extreme flow of field with a very high speed 
and energy to remove and transmit soil particles downhill slope.

Rainfall erosivity is defined as the aggressiveness of rain to induce erosion to soil (Lal's, 2001). It is a major contributor to gully erosion (Romkens, Helming and Prasad, 2002). The higher the amount of rainfall, the higher the quantity of soil particles that are dissolved, displaced and moved away which causes gully erosion (Chimelu, Okeke, Nwosu, Ibe, Ndukwu and Ugwuobi, 2013). From Lal's (2001), Romkens et al's (2002) and Chimelu et al's (2013) definitions of rainfall erosivity, it can be distilled that the power of rainfall to cause erosion is known as erosivity and it is this that really influences the removal of soil particles in the rainsplash-sheet-rillgully erosion processes with its accompanying adverse impacts. Therefore, the issue of gully erosion deserves priority attention to mitigate its dire consequences on the land status and environmental quality. This paper focuses on reviewing rainfall erosivity as a natural factor of gully erosion.

\subsection{Statement of the Problem}

Rainfall erosivity causes gully erosion in that the duration, intensity and frequency of rainfall induces the occurrence of gully development (Romkens et al, 2002). It affects all processes of erosion be it splash, sheet, rill and gully erosion. Gully erosion is the worst stage of all types of erosion and it affects several soil functions and hence soil quality (Poesen, 2011; Abdulfatai, Okunlola, Akande, Momoh and Ibrahim, 2014). It is the most destructive form of erosion damaging farmlands and difficult to resolve (Moges and Holden, 2009). It is one of the major causes of the resevoir situation in the Nile River Basin (Zegeye et al, 2010). Narain (2005) saw gully erosion as a threat to soil productivity. It causes water bodies' eutrophication (Istvanovics, 2009). Abdulfatai et al (2014) emphasized that many lives have been lost to gully erosion. According to them, some have fallen into the gullies and sustained various degrees of injury while some instances were also reported where people drowned in some of the gully sites.

The higher the amount of rainfall, the higher the quantity if soil particles that are to be dissolved, displaced and moved away (Chimelu et al, 2013). In the view of Yang, Kanae, Oki, Koike and Musaike (2003), changes in precipitation volume and intensity caused by climatic changes increases available rainfall for detaching and carrying sediments. They estimated that the global average erosion is projected to increase approximately by $9 \%$ in 2090 due to climatic changes.

\subsection{Objective}

The objective of this paper is to review rainfall erosivity as a natural factor of gully erosion.

\section{CONCEPTUAL FRAMEWORK: SUSTAINABLE DEVELOPMENT}

This research is based on the concept of Sustainable Development. In the opinion of World Conference on Environment and Development (WCED) (1987), sustainable development is the development that meets the needs of the present without comprising the ability of future generations to meet their own needs.

Morelli (2010) saw sustainable development as meeting the resources and service needs for current and future generations without compromising the health of the ecosystems that provide them and more specifically as a condition of balance, resilience and interconnection that allows human society to satisfy its needs while neither exceeding the capacity of its supporting ecosystems to continue to regenerate the services necessary to meet those needs nor by our actions diminishing biological diversity. Rainfall erosivity is a major factor of gully erosion which this research tends to review so as to build sustainability into the management of the menace.

\section{METHOD}

This research made use of a review of academic articles, textbooks, internet materials, conference papers and thesis both published and unpublished on gully erosion and rainfall erosivity as one of its natural factors. The researchers gathered 52 materials: journal articles, textbooks, seminar and conference papers for this research but summarized the characteristics of 10 that were considered more relevant to rainfall erosivity as a natural factor of gully erosion for the review.

\section{LITERATURE REVIEW OF RAINFALL EROSIVITY AS A FACTOR OF GULLY EROSION}

Desir and Marin (2005) saw rainfall as one of the drivers of soil erosion owing to its potential for detaching soil particles and subsequent displacement. Rainfall is an important physical parameter that affects gully erosion in tropical regions (Thomas, 2009). Rainfall is the main source of energy for detachment and transport of soil particles from soil profile (Jain and Kothiyari, 2009). Rainfall erosivity is the potential ability of rainfall to cause soil loss (Silva, 2004). Morgan (2005) stated that erosivity is an important characteristic of rainfall because all things being equal, more erosion is caused by rainstorm of high intensity than by several storms of low intensity. 
Erosivity is related to the kinetic energy of rainfall which can be related to the amount of rainfall and intensity. Gonzalez-Hidalgo, Pena-Monne and Luis (2007) opined that a few very intense rainfall events are responsible for the largest part of soil erosion and sediment delivery in West Mediterranean. Rainfall erosivity is the impact of the kinetic energy of raindrops on soil; higher velocity and larger size of the raindrops result in higher kinetic energy and higher soil loss (Isikwue, Ocheme and Aho, 2015). Labriere, Locatelli, Frevcon and Bernoux, (2015) stated that the large amount and high intensity of rainfall in the humid tropics causes soil erosion in the region to reach dramatic levels.

Wischmeier and Smith (1978) asserted that rainfall erosive energy indicates the volume of rainfall and runoff but a long and slow rain may have some erosive energy value as a shorter rain at much higher intensity as erosion increases with intensity $\left(\mathrm{I}_{30}\right)$ which indicates prolonged peak rates of detachment and runoff. The equation of Wischmeier and Smith (1959) is:

$$
R=\frac{1}{n} \sum_{j=1}^{n}\left(\sum_{k=1}^{m}(E)\left(I_{30}\right)\right)
$$

where $\mathrm{R}$ is the average annual rainfall, $\mathrm{E}$ is the kinetic energy $\left(\mathrm{mJha}^{-1}\right), \mathrm{I}_{30}$ is the maximum 30 minutes rainfall intensity $\left(\mathrm{cmh}^{-1}\right), \mathrm{J}$ is the average of the number of years used to produce the average, $\mathrm{K}$ is the index of number of storms in a year, $\mathrm{n}$ is the number of years used to obtain the average and $\mathrm{m}$ is the number of storms in each year.

The Universal Soil Loss Equation (USLE) by Wischmeier (1959) included a method for calculating storm kinetic energy $\mathrm{E}$ and erosivity (R). The storm kinetic energy can be computed as the sum of each intensity group, $\mathrm{I}_{\mathrm{i}}$ as :

$$
\mathrm{E}=\left(210+89 \log \mathrm{I}_{\mathrm{i}}\right) \mathrm{D}
$$

where $E$ is the kinetic energy, $I_{i}$ is the rainfall intensity and $\mathrm{D}$ is rain depth for intensity group.

The soil loss by and large depends on rainfall energy known as erosivity index $\left(\mathrm{EI}_{30}\right)$ which is represented by $\mathrm{R}$ factor in (USLE) which is the numerical descriptor of the ability of rainfall to erode soil (Wischmeier and Smith, 1959). According to them, $\mathrm{EI}_{30}$ is a function of total rainfall, rainfall distribution, storm intensity, storm frequency and terminal velocity of the rainfall.

Rainfall erosivity expressed as R-Factor in RUSLE is the summation of the total storm energy $(€)$ of an erosive rainfall event times its corresponding maximum intensity over a time span of 30 minutes $\left(\mathrm{I}_{30}\right)$ within a certain period (Brown and Foster, 1987). Wischmeier and Smith (1958) reported that when factors other than rainfall are held constant, soil loss is directly proportional to $\mathrm{R}$ factor of USLE. Brodie and Rosewell (2007) found out that rainfall intensity is a contributing factor to the amount of suspended particles washed from urban areas during storms. Hence, they postulated that the square of rainfall kinetic $\left(\mathrm{I}^{2}\right)$ provide a measure of the rainfall kinetic energy (KE) available for wash off process.

Bols (1978) proposed a formular for calculating the $\mathrm{R}$ factor in Indonesia in a model:

$$
\mathrm{R}=\frac{2.5 P^{2}}{100(0.073 P+0.73)}
$$

where $\mathrm{P}=$ Annual Precipitation in millimetres and $\mathrm{R}$ is in $\left[\mathrm{MJmmha}^{-1} \mathrm{hr}^{-1} \mathrm{yr}^{-}{ }^{1}\right.$ ]

Fornis, Vermeuleub and Nieuwenhuis (2005) studied soil erosion process, specifically detachment of soil particles by raindrop impact and suggested that kinetic energy is a common indicator of raindrops ability to detach soil particles from the soil mass. The aggressiveness of rainfall or its capacity to cause detachment can be expressed in terms of drop size, rainfall intensity and kinetic energy in the Hindu-Kush Himalayas (Ramprasad, Kothyari and Pandi, 2000). Fuhrer, Benistoton, Fischlon, Frei, Goyette, Jasper and Pfister (2006) predicted increasing trends of water erosion for Switzerland under future climate change due to more frequent and heavy rainfall during winter.

Simmons and Rickson (2008) stated that climate change in the United Kingdom is expected to affect the intensity, amount, frequency and type of rainfall with an increasing trend for heavy (greater than $10 \mathrm{mmd}^{-1}$ ) and extreme (greater than $95^{\text {th }}$ percentile) rainfall events. Salako (2008) noted a decreasing trend of rainfalls in West Africa where rainfall erosivity is considered to be high. He made it known that high intensities of rainfall can result in high rainfall erosivity in regions with high amount of rainfall compared with those of relatively low amounts of rainfall.

When flow velocity fall due to a reduction in slope gradient, flow transport capacity is reduced and deposition of eroded material may occur (Morgan, 2005). According to him, the velocity of rainfall and its intensity are related: for instance a $1 \mathrm{~mm}$ diameter raindrop has a thermal velocity of $4 \mathrm{~ms}^{-1}$ while a $5 \mathrm{~mm}$ diameter raindrop has a terminal velocity of $9 \mathrm{~ms}^{-1}$; that means the greater the diameter of raindrop, the greater the terminal velocity. Defra (2005) pointed out that the slope steepness along with the soil texture affects the level of risk of soil erosion by overland flow. He noted that very light soil with low organic matter content on gentle slope in low rainfall areas can erode severely and that the length of a storm drop affects raindrop detachment rates. According to him, significant soil erosion events in England are generally associated with rainfall intensities of $>4 \mathrm{~mm}$ per hour and rainfall quantities $>15 \mathrm{~mm}$ per day. 
Wang, Zheng, Romkens and Darboux (2010) opined that erosivity is expended in several components: rainfall power (the product of total amount of incident rainfall energy and intensity) runoff power (the product of flow rate or flow gradient), seepage power (the product of seepage gradient and flow gradient). Ando, Antwi, Watatsuiki and Atakora (2012) showed in their study that the monthly rainfall amount throughout Ghana attained the erosive limit of $20-25 \mathrm{~mm}$ which makes them erosive; the erosion rates are therefore expected in the major rainy season, especially in July when soils are largely bare.

Lee and Lee (2006) presented a model for estimating soil loss using remotely sensed geospatial data which improves soil loss. They calculated rainfall erosivity factor, R using Toxopeus equation Korea Institute of Construction Technology (KICT) (1992) which is well known for its superiority in Korea :

$$
\mathrm{R}=38.5+0.35 \times \mathrm{Pr}
$$

where $\mathrm{R}$ is rainfall erosivity factor and $\mathrm{Pr}$ is the annual average rainfall.
Average annual soil loss (A) in erosion is seen as a multiplier of rainfall erosivity (the R-factor); the resistance of the environment which encompasses $\mathrm{K}$ (soil erodibility), LS (the topographic factor), C (plant cover) and $\mathrm{P}$ (erosion control practices) (Wischmeier and Smith, 1978). The equation is given as:

$$
\mathrm{A}=\mathrm{R} \times \mathrm{K} \times(\mathrm{LS}) \times \mathrm{C} \times \mathrm{P}
$$

For Southern Africa, Hudson (1986) reported that the only intensities above $1 \mathrm{inch} / \mathrm{hr} \quad(2.54 \mathrm{~cm} / \mathrm{hr})$ caused significant splash erosion. His index KE $>1$ considers only the energy of rain falling at intensities $>25.4 \mathrm{~mm}$. He calculated kinetic energy using:

$$
\mathrm{KE}=29.8-\underline{127.5 \quad[\mathrm{~J}]}
$$

I $\quad\left[\mathrm{m}^{2} \times \mathrm{mm}\right]$ where $\mathrm{I}$ is storm

intensity $(\mathrm{mm} / \mathrm{h})$.

Rainfall erosivity is limited due to lack of long term series rainfall data and lack of correlation with measured soil losses (Gabrie, 2006

\begin{tabular}{|c|c|c|c|c|c|c|}
\hline $\begin{array}{l}\text { S/ } \\
\mathbf{N}\end{array}$ & $\begin{array}{l}\text { Author(s } \\
\text { ) }\end{array}$ & $\begin{array}{l}\text { Topic of } \\
\text { Research }\end{array}$ & Method(s) & Result & Recommendation(s) & Conclusion \\
\hline 1 & $\begin{array}{l}\text { Andoh, } \\
\text { Antwi, } \\
\text { Wakatsui } \\
\text { ki and } \\
\text { Atakora } \\
\text { Eric } \\
(2012) \text {. }\end{array}$ & $\begin{array}{l}\text { Estimation of } \\
\text { Soil Erodibility } \\
\text { and Rainfall } \\
\text { Erosivity } \\
\text { Patterns in the } \\
\text { Agroecological } \\
\text { zones of } \\
\text { Ghana. }\end{array}$ & $\begin{array}{l}\text { Experimentat } \\
\text { ion } \\
\text { (laboratory } \\
\text { analysis) }\end{array}$ & $\begin{array}{l}\text { The key result is that } \\
\text { erosivity is least in } \\
\text { dry season and } \\
\text { greatest in the major } \\
\text { rainy season. }\end{array}$ & $\begin{array}{l}\text { There should be } \\
\text { sustainable utilization } \\
\text { of the country's land } \\
\text { resources. }\end{array}$ & $\begin{array}{l}\text { It was concluded that } \\
\text { the monthly rainfall } \\
\text { amount in the study } \\
\text { area attained the } \\
\text { erosive limit of } 20 \text { - } \\
25 \mathrm{~mm} \text { and is therefore } \\
\text { erosive in nature. }\end{array}$ \\
\hline 2 & $\begin{array}{l}\text { Brodie, } \\
\text { and } \\
\text { Rosewell } \\
(2007) .\end{array}$ & $\begin{array}{l}\text { Theoretical } \\
\text { Relationship } \\
\text { between } \\
\text { Rainfall } \\
\text { Intensity and } \\
\text { Kinetic Energy } \\
\text { Variants } \\
\text { associated with } \\
\text { Storm Water } \\
\text { Particle Wash } \\
\text { off. }\end{array}$ & $\begin{array}{l}\text { Experimentat } \\
\text { ion } \\
\text { (Laboratory } \\
\text { analysis) }\end{array}$ & $\begin{array}{l}\text { Average rainfall } \\
\text { intensity is based on } \\
\text { a rainfall duration } \\
\text { that varies from } \\
\text { event to event }\end{array}$ & $\begin{array}{l}\text { Variants KE and M } \\
\text { should be effectively } \\
\text { interchangeable if } \\
\text { used in particle wash } \\
\text { off estimation. }\end{array}$ & $\begin{array}{l}\text { It was concluded that } \\
\text { average storm event } \\
\text { rainfall intensity is an } \\
\text { appropriate substitute } \\
\text { for the constant } \\
\text { stimulated rainfall } \\
\text { intensity. }\end{array}$ \\
\hline 3 & $\begin{array}{l}\text { Gonzalez } \\
\text {-Hidalgo, } \\
\text { Pena- } \\
\text { Monne } \\
\text { De Luis } \\
\text { (2007). }\end{array}$ & $\begin{array}{l}\text { A Review of } \\
\text { Daily Soil } \\
\text { Erosion in } \\
\text { Western } \\
\text { Mediterranean } \\
\text { Areas. }\end{array}$ & $\begin{array}{l}\text { Literature } \\
\text { review }\end{array}$ & $\begin{array}{l}\text { One of the results is } \\
\text { that the amount of } \\
\text { total soil eroded } \\
\text { tremendously varied } \\
\text { from one place to } \\
\text { another. }\end{array}$ & $\begin{array}{l}\text { Erosion values } \\
\text { should be presented } \\
\text { within a temporal } \\
\text { context; complete } \\
\text { daily data should be } \\
\text { published and } \\
\text { requested by editors. }\end{array}$ & $\begin{array}{l}\text { It was concluded that } \\
\text { inspite of the high } \\
\text { variability between } \\
\text { sites, years and } \\
\text { different approaches, } \\
\text { over } 50 \% \text { of soil } \\
\text { eroded annually } \\
\text { belongs to just three }\end{array}$ \\
\hline
\end{tabular}

Table.1: Summary of Characteristics of some of the Studies that described Rainfall Erosivity as a natural factor of Gully Erosion 


\begin{tabular}{|c|c|c|c|c|c|c|}
\hline $\begin{array}{l}\mathbf{S} / \\
\mathbf{N}\end{array}$ & $\begin{array}{l}\text { Author(s } \\
\text { ) }\end{array}$ & $\begin{array}{l}\text { Topic of } \\
\text { Research }\end{array}$ & Method(s) & Result & Recommendation(s) & Conclusion \\
\hline & & & & & & daily erosion events. \\
\hline 5 & $\begin{array}{l}\text { Labriere, } \\
\text { Locatelli, } \\
\text { Laumoni } \\
\text { er, } \\
\text { Freycon } \\
\text { and } \\
\text { Bernoux. } \\
(2015) .\end{array}$ & $\begin{array}{l}\text { Soil Erosion in } \\
\text { the Humid } \\
\text { Tropics: A } \\
\text { Systematic } \\
\text { Quantitative } \\
\text { Review. }\end{array}$ & $\begin{array}{l}\text { Literature } \\
\text { review, } \\
\text { physical } \\
\text { measurement } \\
\text {, } \\
\text { experimentati } \\
\text { on } \\
\text { (laboratory } \\
\text { analysis) }\end{array}$ & $\begin{array}{l}\text { Soil loss was } \\
\text { maximum on bare } \\
\text { soils and strikingly } \\
\text { exceeded that of all } \\
\text { other land use types. } \\
\text { Minimum soil loss } \\
\text { was found in forests. }\end{array}$ & $\begin{array}{l}\text { Implementation of } \\
\text { sound practices of } \\
\text { soil and vegetation } \\
\text { measurement. }\end{array}$ & $\begin{array}{l}\text { It was concluded that } \\
\text { soil erosion in the } \\
\text { humid tropics is } \\
\text { concentrated both } \\
\text { spatially and } \\
\text { temporally and that } \\
\text { low and ground layers } \\
\text { of vegetation are } \\
\text { essential in mitigating } \\
\text { soil erosion. }\end{array}$ \\
\hline 6 & $\begin{array}{l}\text { Lee and } \\
\text { Lee } \\
(2006) .\end{array}$ & $\begin{array}{l}\text { Scaling Effect } \\
\text { for estimating } \\
\text { Soil Loss in } \\
\text { the RUSLE } \\
\text { Model using } \\
\text { remotely } \\
\text { sensed geo- } \\
\text { spatial data in } \\
\text { Korea. }\end{array}$ & $\begin{array}{l}\text { Use of } \\
\text { Geographic } \\
\text { Information } \\
\text { System (GIS) }\end{array}$ & $\begin{array}{l}\text { The L- and S- factor } \\
\text { are very sensitive to } \\
\text { the spatial resolution } \\
\text { while the remaining } \\
\text { factors are not } \\
\text { sensitive. }\end{array}$ & $\begin{array}{l}\text { Since the spatial } \\
\text { resolution is very } \\
\text { sensitive, caution } \\
\text { needs to be taken in } \\
\text { selecting the grid size } \\
\text { for estimating soil } \\
\text { loss using numerical } \\
\text { modeling approach. }\end{array}$ & $\begin{array}{l}\text { The conclusion was } \\
\text { made that the L- and } \\
\text { S- factor is sensitive. } \\
\text { The optimum } \\
\text { resolution for soil loss } \\
\text { came out to be } 125 \mathrm{~m} \text {, } \\
\text { but it may be } \\
\text { dependent on the } \\
\text { selection of model } \\
\text { and quality of geo- } \\
\text { spatial data. }\end{array}$ \\
\hline 7 & $\begin{array}{l}\text { De Silva } \\
\text { Alexandr } \\
\text { e Marco } \\
(2004) .\end{array}$ & $\begin{array}{l}\text { Rainfall } \\
\text { Erosivity Map } \\
\text { for Brazil. }\end{array}$ & $\begin{array}{l}\text { Literature } \\
\text { review, } \\
\text { Geographic } \\
\text { Information } \\
\text { System } \\
\text { (GIS). }\end{array}$ & $\begin{array}{l}\text { North-Western } \\
\text { region had the } \\
\text { highest values of } \\
\text { erosivity while the } \\
\text { North-Eastern region } \\
\text { showed the lowest } \\
\text { annual values of } \\
\text { erosivity. }\end{array}$ & $\begin{array}{l}\text { Adoption of } \\
\text { conservative } \\
\text { practices especially } \\
\text { in the development of } \\
\text { technology. }\end{array}$ & $\begin{array}{l}\text { The conclusion made } \\
\text { was that the major } \\
\text { part of the study area } \\
\text { revealed annual } \\
\text { erosivity values } \\
\text { classified as strong. }\end{array}$ \\
\hline 8 & $\begin{array}{l}\text { Simmons } \\
\text { and } \\
\text { Rickson } \\
(2008) \text {. }\end{array}$ & $\begin{array}{l}\text { Increasing } \\
\text { Rainfall and } \\
\text { Soil Erosion. }\end{array}$ & $\begin{array}{l}\text { Observation } \\
\text { of climate } \\
\text { change } \\
\text { modeling. }\end{array}$ & $\begin{array}{l}\text { The key result is that } \\
\text { the interception of } \\
\text { long term rainfall } \\
\text { data sets and } \\
\text { increasingly accurate } \\
\text { global and regional } \\
\text { scale climate models } \\
\text { led to the general } \\
\text { acceptance that } \\
\text { climate change has } \\
\text { resulted in } \\
\text { significant shifts in } \\
\text { rainfall } \\
\text { characteristics. }\end{array}$ & $\begin{array}{l}\text { Effective on-farm } \\
\text { and catchment scale } \\
\text { and water } \\
\text { management } \\
\text { programmes should } \\
\text { be devised to } \\
\text { mitigate the menace. }\end{array}$ & $\begin{array}{l}\text { It was concluded that } \\
\text { changes in rainfall } \\
\text { patterns have been } \\
\text { observed and are } \\
\text { predicted for the } \\
\text { future. }\end{array}$ \\
\hline
\end{tabular}




\begin{tabular}{|c|c|c|c|c|c|c|}
\hline $\begin{array}{l}\mathbf{S} / \\
\mathbf{N}\end{array}$ & $\begin{array}{l}\text { Author(s } \\
\text { ) }\end{array}$ & $\begin{array}{l}\text { Topic of } \\
\text { Research }\end{array}$ & Method(s) & Result & Recommendation(s) & Conclusion \\
\hline 9 & $\begin{array}{l}\text { Wang, } \\
\text { Zheng, } \\
\text { Romkens } \\
\text { and } \\
\text { Darboux } \\
(2013) .\end{array}$ & $\begin{array}{l}\text { Soil Erodibility } \\
\text { for Water } \\
\text { Erosion: A } \\
\text { Perspective } \\
\text { and Chinese } \\
\text { Experiences. }\end{array}$ & $\begin{array}{l}\text { Literature } \\
\text { review }\end{array}$ & $\begin{array}{l}\text { For many soils, the } \\
\text { erodibility factor } \\
\text { USLE and RUSLE } \\
\text { equations cannot be } \\
\text { obtained in a reliable } \\
\text { and satisfactory } \\
\text { manner from the } \\
\text { nomograph; soil } \\
\text { erodibility can be } \\
\text { predicted from a } \\
\text { combination of } \\
\text { physical properties } \\
\text { and chemical } \\
\text { parameters. }\end{array}$ & $\begin{array}{l}\text { Due to the large } \\
\text { difference between } \\
\text { dry and wet season, } \\
\text { seasonal K values } \\
\text { should be calculated } \\
\text { to obtain reasonable } \\
\text { and accurate USLE- } \\
\text { based predictions. }\end{array}$ & $\begin{array}{l}\text { All conducted } \\
\text { researches came to } \\
\text { similar conclusions } \\
\text { and proposed that the } \\
\text { increases in soil } \\
\text { erodibility were due } \\
\text { to decreases in the } \\
\text { percentage of water } \\
\text { stable aggregation and } \\
\text { increases in the } \\
\text { surface water content } \\
\text { due to snow melt. }\end{array}$ \\
\hline 10 & $\begin{array}{l}\text { Wischme } \\
\text { ier and } \\
\text { Smith } \\
(1978) .\end{array}$ & $\begin{array}{l}\text { Predicting } \\
\text { Rainfall } \\
\text { Losses- A } \\
\text { Guide to } \\
\text { Conservation } \\
\text { Planning. }\end{array}$ & $\begin{array}{l}\text { Literature } \\
\text { review of } \\
\text { research } \\
\text { works, } \\
\text { laboratory } \\
\text { analysis. }\end{array}$ & $\begin{array}{l}\text { Present soil loss } \\
\text { equations are } \\
\text { substantially less } \\
\text { accurate for } \\
\text { prediction of specific } \\
\text { events than for the } \\
\text { prediction of long } \\
\text { term averages. }\end{array}$ & $\begin{array}{l}\text { The practice of } \\
\text { tillage, mulching and } \\
\text { planting on the } \\
\text { contour should be } \\
\text { encouraged. }\end{array}$ & $\begin{array}{l}\text { The USLE is designed } \\
\text { to predict long-time } \\
\text { average soil losses for } \\
\text { specified conditions. } \\
90 \% \text { of erosion on the } \\
\text { steeply rolling wheat } \\
\text { land was estimated to } \\
\text { derive from runoff. }\end{array}$ \\
\hline
\end{tabular}

Source: Researchers' design, 2017.

\section{RESULTS AND DISCUSSION}

Gully erosion, greatly influenced by rainfall erosivity is the last stage in the rainsplash-sheet-rill-gully erosion processes, and it attracts the attention of most researchers on erosion because of its grave adverse environmental impacts. Erosivity is an important characteristics of rainfall as it the aggressiveness of rain to cause soil erosion (Lal's, 2001). It is the potential ability of rain to cause soil erosion whose extreme type in gully erosion. Various authors such as Chiemelu, et al.(2013), Labriere, et al.(2015) viewed that a high amount and intensity of rainfall indicates a high quantity of soil particles to be eroded. However, Gonzalez-Hidalgo et al. (2007) have a slightly contrary view that a few, very intense rainfall event is responsible for most soil erosion; that inspite of the high variability between sites, years and different approaches, over $50 \%$ of soil is eroded annually as can be seen in Table 1. According to Ramprasad et al. (2000) rainfall can be expressed in terms of drop size, rainfall intensity and kinetic energy in the Hindu-Kush Himalayas. Moreover, various authors concluded that a high kinetic energy is a common indicator of a high rainfall erosivitiy and indeed more gully erosion.

Salako (2008) and Fuhrer et al (2006) opined that climate variability is an important factor to determine rainfall erosivity as there is a decrease in rainfall where rainfall erosivity is considered to be high. Also, climate change affects the intensity, amount, frequency and type of rainfall in the United Kingdom thereby affecting the soil erodibility rate. From Table 1, Wischmeier (1978) stated that if one of the factors (of soil erodibility, topography, plant cover and erosion control practices) tends to zero, the rate of rainfall erosivity will also diminish. From the results of the study by Simmons and Rickson (2008) in Table 1, it can be deduced that the interception of long term rainfall data sets and increasingly accurate global and regional scale climate models leads to the general acceptance that climate change has resulted in significant shifts in rainfall characteristics.

Generally, it can be distilled from the results of the studies reviewed that regions with a high rainfall regime tend to have a high rate of soil erosion because of the significant impact of rainfall intensity and rainfall energy on the soil in question. For example, the South Eastern part of Nigeria which lies on the tropics with high rainfall regime is being devastated by gully erosion exemplified by the Agulu-Nanka-Oko badland in Anambra State, Nigeria. 
The adage that: "prevention is better than cure" rightly applies to gully erosion. Many terrified gullies across the globe, exemplified by the bad lands of Loess Pleteau China and Agulu-Nanka-Oko in Anambra State, Nigeria would not have developed if adequate management strategies were taken at their early stage of formation. In the light of this background and based on this review, the following recommendations are made to reduce the impacts of the forces of raindrops and runoff (rainfall erosivity) that detach and transport soil particles.

1 Plant cover (vegetation) reduces the energy of raindrops and running water by imparting roughness to the flow of water thereby reducing its velocity, hence it will lessen the havoc. Also, planting of the trees with buttress roots should be encouraged to reduce the force of running water.

2 A shift from rain-fed agriculture to dry season farming is very important to avoid tillage of soils during the rains which predisposes them to the forces of raindrops and runoff that detach and transport soil particles in the rainsplash- sheet-rillgully erosion processes.

3 Both the affected people and landholders should be adequately empowered through grants by governments, donor agencies and non-governmental organizations (NGOs) prevent formation of gullies because they know when rills begin to occur in their localities and as such can stop their expansion into gullies by using some adaptive measures based on their indigenous knowledge.

4 Training the affected people and landholders on some adaptive measures to soil erosion is a major component in the management of gully erosion. These stakeholders should be trained to enhance those adaptive measures such as tree planting, crop rotation, use of compost as manure and ploughing across the slope, rather than along it which obtains in some communities today, for the management of rills wherever it occurs to prevent them from developing into gullies.

5 Ministries, institutions and agencies responsible for the provision of rainfall data daily, monthly and yearly should make efforts to do so, update them and make them accessible to the public as this is not the situation in most countries of the world. With availability of data, researchers should be encouraged by government and donor agencies to conduct studies to develop regression equation (models) for computing rainfall erosivity and soil losses for different localities across the globe.

6 Diversion of water away from erosion prone gullies, thus dispersing the erosive power of the water over well vegetated areas. Diversion banks are a simple way of achieving this. Moreso, natural drains, footpaths and culverts should be properly managed through maintenance to minimize the erosive power of runoff.

\section{CONCLUSION}

This study was conducted in the view of the fact that rainfall erosivity is a natural factor influencing the formation of gullies that leads to the destruction of the environment which is the destruction of man. From the review of studies on rainfall erosivity as a natural factor of gully erosion which is the most visible, extreme and last stage in the rainsplash-sheet-rill-gully erosion processes and based on the results, this study concludes that locally grown solutions in terms of adaptive measures by the affected people and landholders should be used to reduce the impact of rainfall erosivity in detaching and transporting soils to form gullies and triggering the expansion of existing gullies.

\section{ACKNOWLEDGEMENT}

We appreciate the grace and empowerment of God Almighty who has been our source of strength from beginning to completion of this work. We also commend the effort of the relations, friends and well- wishers of the authors who contributed both financially and otherwise for making this review a success. Our gratitude extends to the Vice chancellor and the entire stakeholders of Chukwuemeka Odumegwu Ojukwu University, Uli, Anambra State, Nigeria for providing a platform for the study of Environmental Management. To all the lecturers, head of department and dean of the Environmental Sciences, we appreciate their collective efforts in making sure that the goal of environmental management is achieved in the institution. We are highly indebted to the chief author, Mr. Igwe, P.U. for his tireless effort towards an extensive research on the materials used for the review. We cannot fail to commend and appreciate the works of various authors used for the review. Finally, we thank the entire students of Environmental Management especially her final year students for their support throughout the review.

\section{REFERENCES}

[1] Abdulfatai, I.A., Okinlola, I.A., Akande, W.G., Momoh, L.D., and Ibrahim, K.O. (2014). Review of Gully Erosion in Nigeria: Causes and Possible Solutions. Journal of Geosciences and Geomatics, 2(3):125-129.

[2] Abraham, C.M. (2010). Implications of Gully Development on Agricultural Production in Akwa Ibom State. Unpublished Ph.D. Thesis submitted to 
the University of Uyo, Uyo Akwa Ibom State, Nigeria.

[3] Ando, H.F., Antwi, B.O., Wokatsuiki, T., and Atakora, E.T. (2012). Estimation of Soil Erodibility and Rainfall Erosivity Patterns in the Agroecological Zone of Ghana. Journal of Soil Science and Environmental Management, 3(11):275-279.

[4] Bols, P.L. (1978). The Iso-erodent Maps of Java and Madura: Report of Belgian Technical Assistance Project ATA 105, Bogor, Indonesia: Soil Research Institute, Bogor.

[5] Brodie, L., and Rosewell, C. (2007). Theoritical Relationship between Rainfall Intensity and Kinetic Energy Variants Associated with Storm Water Particle Wash Off. Journal of Hydrology, 340:40-47.

[6] Brown, L.C., and Foster, G.R. (1987). Storm Erosivity using Idealized Intensity Distributions. Transactions of American Society of Agricultural Engineers, 30:379-386.

[7] Chimelu, N., Okeke, F., Nwosu, K., Ibeh, C., Ndukwe, R., and Ugwuoti, A. (2013). The Role of Surveying and Mapping in Erosion Management and Control: Case Study of Omagba Erosion Site, Onitsha, Anambra State, Nigeria. Journal of Environment and Earth Science, 3(11):129-137.

[8] Dada, S. (2002). An Investigation on the Physical and Socioeconomic Determinants of Soil Erosion in the Harashe Highlands, Eastern Ethiopia. Land Degradation and Development, 14:69-81.

[9] Defra, (2005). Controlling Soil Erosion: A Manual for the Assessment and Management of Agricultural Land at Risk of Water Erosion in Lowland England. Published by the Department for Environment, Food and Rural Affairs, London.

[10] Desir, G., and Marin, C. (2005). Factors Controlling the Erosion Rates in a Semi-arid Zone (Bardenas Realest NE Spain). Catena, 71:31-40.

[11] Ehiorobo, J.O., and Audu, H.A. (2012). Monitoring of Gully Erosion in an Urban Area using Geographic Information Technology. Journal of Emerging Trends in Engineering and Applied Sciences, 3(2):270-275.

[12] Ezeigwe, P.C. (2015). Evaluation of Socioeconomic Impacts of Gully Erosion in Nkpor and Obosi. Environmental Research, 7(7):34-38.

[13]Fornis, R.L., Vermeuleub, H.R., and Niuwenhuis, J.D. (2005). Kinetic-energy Rainfall Intensity Relationship for Central Cebu, Philippines for Soil Erosion Studies. Journal of Hydrology, 300:20-32.

[14] Fuhrer, J., Beniston, M., Fischlin, A., Frei, C., Goyette, S., Jasper, K., and Pfister, C. (2006). Climate Risks and their Impacts on Agriculture and Forests in Switzerland. Climate Change, 71:79-102.
[15] Gabrie, D. (2006). Assessing the Modified Fournier Index and the Precipitation Concentration Index for some European Countries. In: Boardman, J. And Poesen, J. (eds). Soil Erosion in Europe. Wiley and Sons, Ltd. 2(14):675-684.

[16] Gonzalez-Hidalgo, J.C., Pena-Monne, J.L., and De Luis, M. (2007). A Review of Daily Soil Erosion in Western Mediterranean Areas. Catena, 71:193-199.

[17] Hudson, N.W. (1986).Soil Conservation. Batsford Limited, London, United Kingdom, p.324.

[18] Igbokwe, J.I. (2008). Gully Erosion Mapping/Monitoring in Parts of South Eastern Nigeria. Paper Presented at Department of Surveying and Geoinformatics, Nnamdi Azikiwe University, Awka, Anambra State. Accessed at: http:/www.nasrda.or/doc/jibokwe.pdf on $02 \quad 11$ 2017.

[19] Isikwue, M.O., Ocheme, J.E., and Aho, M.I. (2015). Evaluation of Rainfall Erosivity Index for Abuja. Nigeria Lombardi Method. Nigeria Journal of Technology, 34(1):52-63.

[20] Istavonics, V. (2009). Eutrophication of Lakes and Reservoirs. Encyclopaedia of Inland Waters, 1:157165.

[21] Jain, S.K., and Kothyari, U.C. (2010). Estimation of Soil Erosion and Sediment Yield using Geographic Information System (GIS). Hydrological Sciences Journal, 45(5):771-786.

[22] Kalu, A.C. (2001). Soil Erosion and Landslides: $21^{\text {st }}$ Century Issues and Challenges to Rural Development in Nigeria. Unpublished MURP Seminar Paper: Department of Urban and Regional Planning, Abia State University, Uturu Abia State, Nigeria.

[23] Korea Institute of Construction Technology (KICT) (1992). The Development of Selection Standard for Calculation Method of Unit Sediment Yield in River. KICT, 89-WR-113. Research Paper (in Korean), 1992.

[24] Labriere, N., Locatelli, B., Laumonier, Y., Freycon, V., and Bernoux, M. (2015). Soil Erosion in the Humid Tropics: A System of Quantitative Review. Agriculture, Ecosystems and the Environment, 203:127-139.

[25]Lal's, R. (2001). Soil Conservation for Sequestration. Proceedings of the $10^{\text {th }}$ International Soil Conservation Organisation Meeting, $24^{\text {th }}-29^{\text {th }}$ May 1999, West Lafayette, pp.459-465.

[26]Lee, G.S., and Lee, K.H. (2006). Scaling Effect for Estimating Soil Loss in the RUSLE Model using Remotely Sensed Geospatial Data in Korea. Hydrology and Earth System Sciences, 3:135-137. 
[27] Moges, A., and Holden, N.M. (2009). Land Cover Change and Gully Erosion Development in Umbulo Watershed, Southern Ethiopia. Mountain Research and Development, 29(3):265-276.

[28] Morelli, J. (2010). Economic Sustainability and the Preservation of Environmental Management. Journal of Environmental Management, 14(8):771778.

[29] Morgan, R.P.C. (2005). Soil Erosion and Conservation, ( $3^{\text {rd }}$ Edition). Blackwell Publishing Ltd.

[30] Narain, P. (2008). Dry Land Management in Arid Ecosystem. J. Indian Soc. Soil Sci, 56:337-347.

[31] Ofomata, G.E.K. (2000). Missing Links in the management of Soil Erosion Problems in Nigeria. In: Environmental Pollution and Management in the Tropics, Snaap Publishers.

[32]Pathak, P., Wani, S.P., and Sudi, R. (2005) Gully Control in SAT Watersheds. Global Theme on Agroecosystems. International Crops Research Institute for the Semi-Arid Tropics, p.28.

[33] Poesen, J. (2011). Challenges in Gully Erosion Research. Landform Analysis, 17:5-9.

[34] Poesen, J., Vandekerchove, L., Nachergaele, D.D., Wisdenes, G., and Verstraeten, G. (2002). Gully Erosion in Dry Land environment. In: Dry Land Rivers. Hydrology and Geomorphology of Semi-arid Channels, pp.229-262.

[35] Ramprasad, B.K., Kothyari, B.P., and Pande, R.K. (2000). Evaluation of Rainfall Erosivity in Bheta Gad Catchment, Kuman Hills of Littar, Pradesh, Central Himalayas. The Environmentalist, 20:301308.

[36] Romkens, M.J., Helming, K., and Prasad, S.N. (2002). Soil Erosion under Different Rainfall Intensities, Surface Roughness and Soil Water regimes. Catena, 46(2-3):103-173.

[37] Salako, F.K. (2005). Rainfall Variability and Kinetic Energy in Southern Nigeria. Climate Change, 86:151-164.

[38] Shit, P.K., and Maiti, R. (2002). Rill Gully Erosion. In: Bad Land Topography: Field Measurement and Monitoring (A Case Study on the Western Part of West Bengal, India). LAP LAMBERT Academic Publishing, Germany, p.136.

[39] Silva, A.M. (2004). Rainfall Erosivity Map for Brazil. Catena, 57:251-259.

[40] Simmons, R.W., and Rickson, R.J. (2008). Increasing Rainfall and Soil Erosion. In: Water and Food, pp.89-96.

[41] Soil Science Society of America (2001). Glossary of Science Terms - Soil Science Society of America,
Modison, WI. Accessed at http:/www.soils.org/sssaglows, 10102017.

[42] Thomaz, E.L. (2009). The Influence of Traditional Steep Land Agricultural Practices on Runoff and Soil Loss. Agriculture, Ecosystems and Environment, 130:23-30.

[43] Umah, K.A., Justin, U., and Braimoh, J. (2016). Investigating the Impacts/Causes of Gully Erosion in Auchi, Nigeria. Journal of Geography, Environment and Earth Science, 4(4):1-13.

[44] United States Global Change Research Information Office (2001). Accessed at [http//www.gcrio.org/geo/soil/html], 20102017.

[45] Wang, B., Zheng, F., Romkens, M.J.M., and Darboux, F. (2013). Soil Erodibility for Water Erosion: A Perspective and Chinese Experiences. Geomorphology, 187:1-10.

[46] Wischmeier, W.H., and Smith, D.D. (1958). Rainfall Energy and its Relationship to Soil Loss. Geophysical Union, 39:285-291.

[47] Wischmeier, W.H. (1959). A Rainfall Erosion Index for a Universal Soil Loss Equation. Soil Science Society of America Proceedings, 23, pp. 246-249.

[48] Wischmeier, W.H., and Smith, D.D. (1978). Predicting Rainfall Erosion Losses - A Guide to Conservation planning. United States Department of Agriculture, Agricultural Handbook, p.58.

[49] World Commission for Environment and Development (WCED) (1987). Our Common Future. Oxford University Press.

[50] Yang, D., Kanae, S., Oki, T., Koike, T., and Musaike, K. (2003). Global Potential Soil Erosion with Reference to Land Use and Climatic Changes. Hydrological Processes, 17:2913-2928.

[51]Zegeye, A.D., Abiy, A.z., and Tebebu, T.Y. (2010). Surface and Subsurface Flow Effect on Permanent Gully Formation and Upland Erosion near Lake Tana in the Northern Highlands of Ethiopia. Hydrology and Earth System Sciences, 14(11):22072217. 